\title{
PENGEMBANGAN MODUL ELEKTRONIK MATA KULIAH DESAIN GRAFIS PADA PROGRAM STUDI PENDIDIKAN TIK
}

\author{
Nurbani $^{1)}$, Sri Koriaty ${ }^{2)}$ \\ ${ }^{1,2}$ Prodi Pendidikan Teknologi Informasi dan Komputer, IKIP PGRI Pontianak \\ Email : ․ㅡurbani05@gmail.com, ${ }^{2}$ skoriaty@gmail.com
}

\begin{abstract}
This study aims to: 1) Produce the Electrocnik Graphic Design module in the P.TIK Study Program, IKIP PGRI Pontianak. 2) Knowing the student's feasibility and response to the Graphic Design electronic module. The research method used in this study is research and development. The research design used the Borg and Gall model. This research variable uses a single variable, namely the development of an electronic module in the Graphic Design course. The object of this study was the second semester students of the ICT Study Program IKIP-PGRI Pontianak 2017/2018. The results of the evaluation of the electronic module by the expert lecturer of the material obtained a score of 102.5 with eligibility criteria and the results of the evaluation of the electronic module by the media expert lecturer obtained a score of 94.5 with eligibility criteria .. While the response of students to electronic modules in a sample trial of 53 students obtained an average score of questionnaire 4 with good criteria. Based on these data it can be concluded that the electronic module application of graphic design developed is feasible and is good to use in the learning process
\end{abstract}

Keywords: Development, Electronic Modules, Graphic Design

\section{INTISARI}

Penelitian ini bertujuan untuk : 1) Menghasilkan modul elektroknik Desain Grafis pada Program Studi P.TIK, IKIP PGRI Pontianak. 2) Mengetahui kelayakan dan respon mahasiswa terhadap modul elektronik Desain Grafis. Metode penelitian yang digunakan dalam penelitian ini adalah penelitian dan pengembangan (Research and Development). Rancangan penelitian menggunakan model Borg and Gall. Variabel penelitian ini menggunakan variabel tunggal yaitu pengembangan modul elektronik matakuliah Desain Grafis. Objek penelitian ini adalah mahasiswa semester II Prodi TIK IKIP-PGRI Pontianak 2017 / 2018. Adapun skor penilaian modul elektronik Desain Grafis oleh dosen ahli materi diperoleh 102,5 dengan kategori layak dan skor penilaian modul elektronik oleh dosen ahli media diperoleh 94,5 dengan kriteria layak.. Sedangkan respon mahasiswa terhadap modul elektronik dengan sampel 53 orang mahasiswa diperoleh rata-rata skor angket 4 dengan kategori baik. Hasil skor tersebut dapat disimpulkan bahwa modul elektronik aplikasi desain grafis yang dikembangkan layak dan baik digunakan dalam proses pembelajaran

Kata Kunci: Pengembangan, Modul Elektronik, Desain Grafis

\section{PENDAHULUAN}

Pendidikan adalah suatu proses untuk membantu manusia dalam mengembangkan dirinya sehingga mampu menghadapi segala perubahan dan permasalahan dengan sikap terbuka. Seiring perkembangan zaman, teknologi berkembang dengan pesat pula. Teknologi banyak digunakan dalam berbagai bidang seperti dalam bidang pendidikan. Teknologi dalam dunia pendidikan banyak digunakan sebagai media pembelajaran sekaligus sebagai alat bantu untuk menguasai sebuah kompetensi berbantu komputer.

Teknologi pendidikan merupakan suatu proses yang sangat kompleks yang meliputi manusia, prosedur, ide, alat, dan organisasi untuk 
menganalisis masalah serta merancang, melaksanakan, menilai, dan mengelola usaha pemecahan masalah yang berhubungan dengan segala aspek belajar [1].

Perkembangan teknologi terjadi begitu cepat menawarkan kebutuhan dalam pembelajaran. Hal ini memungkinkan terjadinya perubahan cara belajar, dari belajar dengan guru di sekolah menjadi belajar mandiri. Belajar mandiri adalah cara efektif mengembangkan diri yang tidak terikat dengan kehadiran guru, pertemuan tatap muka, dan kehadiran di sekolah. Belajar mandiri membutuhkan motivasi, keuletan, keseriusan, tanggungjawab, dan keingintahuan untuk berkembang dan maju. Untuk memudahkan belajar mandiri perlu adanya media yang menunjang tugastugas dosen memotivasi dan meningkatkan pemahaman mahasiswa. Alat bantu secara nyata sangat membantu aktifitas pembelajaran dikelas untuk meningkatkan minat serta hasil belajar.

Mata kuliah Desain Grafis merupakan salah satu mata kuliah yang dipelajari oleh mahasiswa semester II Program Studi TIK IKIP-PGRI Pontianak. Berdasarkan hasil observasi bulan Maret 2017 dan wawancara dengan dosen pengampu matakuliah Desain Grafis, peneliti mendapati bahwa keterampilan mahasiswa dalam bidang desain masih kurang. Bahan ajar juga masih terbatas buku teks yang tersedia di perpustakaan, mahasiswa masih perlu menggunakan bahan ajar lain untuk melatih kemampuan dan keterampilan dalam mendesain. Berdasarkan hasil analisis kebutuhan awal dosen dan mahasiswa yang masih membutuhkan bahan ajar yang bersifat terpadu dan mampu melatih kemampuan mahasiswa dalam mengembangakan keterampilan mendesain suatu karya. Salah satu bentuk bahan ajar adalah modul. Modul adalah satuan program pembelajaran terkecil yang dapat dipelajari mahasiswa secara perorangan karena dapat membantu mahamahasiswa dalam mempelajari dan memahami serta menyelesaikan tugas secara mandiri.

Berdasarkan latar belakang tersebut, dikembangkan modul elektronik pada Mata kuliah Desain Grafis. Pengembangan modul ini diharapkan dapat mengembangkan keterampilan mahasiswa sehingga berdampak pada hasil belajar yang lebih baik.

Peneliti pengembangan yang lain juga pernah dilakukan oleh Najikhah yaitu Keefektifan Multimedia Pembelajaran Interaktif Game Edukasi Dengan Adobe Flash Terhadap Hasil Belajar Pembelajaran IPA Mengenal Berbagai Benda Lagit di Kelas 1 SD N 2 Wergu Kulon Kudus [2]. Dengan adanya pengembangan bahan ajar dengan multimedia diharapkan dapat memberikan sumbangan pemikiran kepada guru atau dosen untuk diterapkan pada proses pembelajaran.

\section{PENDEKATAN PEMECAHAN}

\section{MASALAH}

Metode penelitian yang digunakan dalam penelitian ini adalah penelitian dan pengembangan (Research and Development). Metode penelitian dan pengembangan atau Research and Development adalah metode penelitian yang digunakan untuk menghasilkan produk tertentu, dan menguji keefektifan produk tersebut [3]. Penelitian ini difokuskan pada pengembangan modul elektronik. Metode penelitian Research and Development mempunyai langkah-langkah sebagai yang ditunjukkan pada gambar .

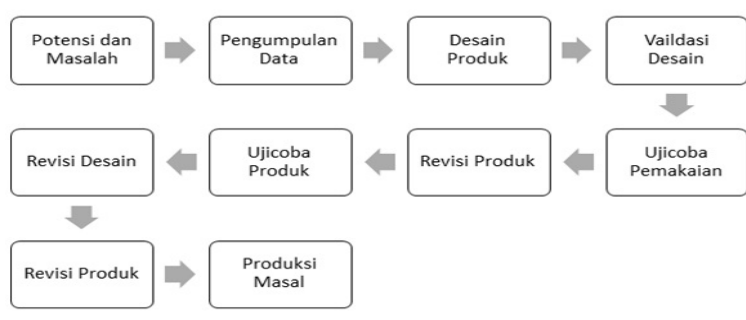

\section{Gambar.1 Langkah-langkah Penggunaan Metode Research \& Development $(R \& D)[3]$}

Variabel penelitian ini menggunakan variabel tunggal yaitu pengembangan modul elektronik matakuliah Desain Grafis.

Subjek penelitian ini adalah mahasiswa semester II Prodi TIK IKIP-PGRI Pontianak yang berjumlah 53 orang. Untuk lebih jelas bisa dilihat pada tabel 1

Tabel 1. Jumlah Subjek Penelitian

\begin{tabular}{|c|c|c|}
\hline \multicolumn{2}{|c|}{ Kelas } & \multirow{2}{*}{ Jumlah } \\
\hline A Pagi & A Sore & \\
\hline 27 & 25 & 53 \\
\hline
\end{tabular}

Teknik pengumpulan data dan instrument penelitian yang digunakan yaitu teknik komunikasi langsung adalah cara mengumpulkan informasi dengan bertatap muka (face to face). Teknik pengumpulan data yaitu wawancara untuk menemukan permasalahan yang harus diteliti. Apabila peneliti ingin mengetahui hal-hal yang lebih mendalam dari responden [4]. Adapun 
wawancara dilakukan kepada dosen pengampu matakuliah Desain Grafis berupa lembar wawancara untuk mendapatkan informasi yang berkaitan dengan penelitian. Observasi merupakan teknik pengumpulan data dengan cara mengamati secara langsung ke lapangan untuk memperoleh keterangan mengenai proses pembelajaran matakuliah Desain Grafis. Selain itu juga metode observasi ini digunakan untuk mengetahui respon atau tanggapan mahasiswa semester 2 Program Studi P.TIK. Teknik komunikasi tidak langsung adalah cara mengumpulkan data dengan menggunakan alat yaitu angket/kuisoner. Kuesioner atau angket ditujukan kepada ahli media, ahli materi dan mahasiswa untuk menilai tingkat kelayakan.

Teknik analisis data yang digunakan dalam penelitian ini yaitu menggunakan statistik deskriptif untuk menganalisis data dengan cara mendeskripsikan atau menggambarkan data yang telah terkumpul.

\section{HASIL DAN PEMBAHASAN}

Berdasarkan hasil informasi dengan dosen dan mahasiswa serta observasi yang dilakukan di Program Studi P.TIK khususnya pada matakuliah Desain Grafis diperoleh potensi yang ada pada kampus tersebut adalah komputer yang sudah cukup memadai untuk dilaksanakannya proses pembelajaran berbasis komputer dan masalah yang ditemukan kemandirian peserta didik masih kurang, dan media maupun bahan ajar yang digunakan guru dalam mengajar masih menggunakan lembar kerja mahasiswa, sehingga proses pembelajaran di kampus tersebut masih kurang optimal

Dalam kegiatan pengumpulan data, peneliti menentukan lingkup materi yang akan dimasukkan dalam modul elektronik berdasarkan diskusi dengan dosen pengampu matakuliah Desain Grafis. Tahap selanjutnya peneliti melakukan studi referensi berkaitan dengan materi Desain Grafis.

Untuk mengembangkan produk berupa modul elektronik aplikasi Desain Grafis, peneliti membuat terlebih dahulu desain modul elektronik sampai pada pembuatan produk. Aplikasi yang digunakan dalam pembuatan modul elektronik adalah Macromedia Flash 8.

Tampilan cover modul elektronik berisi judul, dan tombol navigasi utk masuk ke menu utama.Tampilan cover modul elektronik dapat dilihat pada gambar 2 .

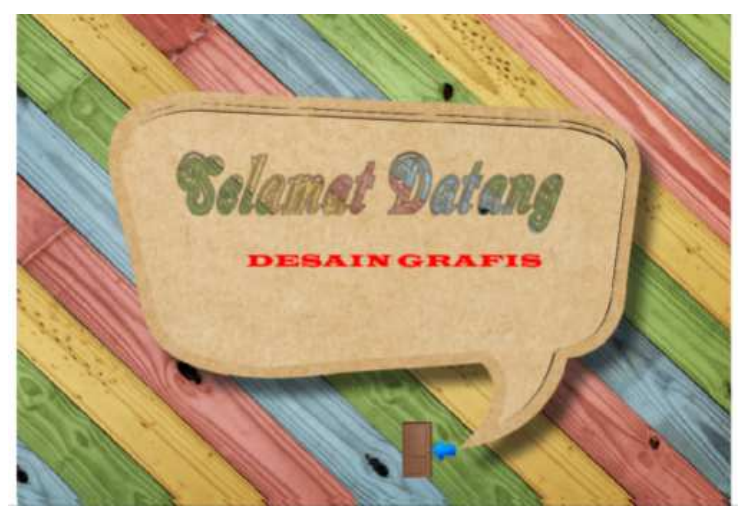

Gambar 2. Desain Cover

Tampilan halaman utama modul elektronik berisi judul dan tombol navigasi (Standar Kompetensi dan Kompetensi Dasar, Indikator, tujuan, Materi, Evaluasi dan Penulis). Tampilan halaman utama modul elektronik dapat dilihat pada gambar 3 .

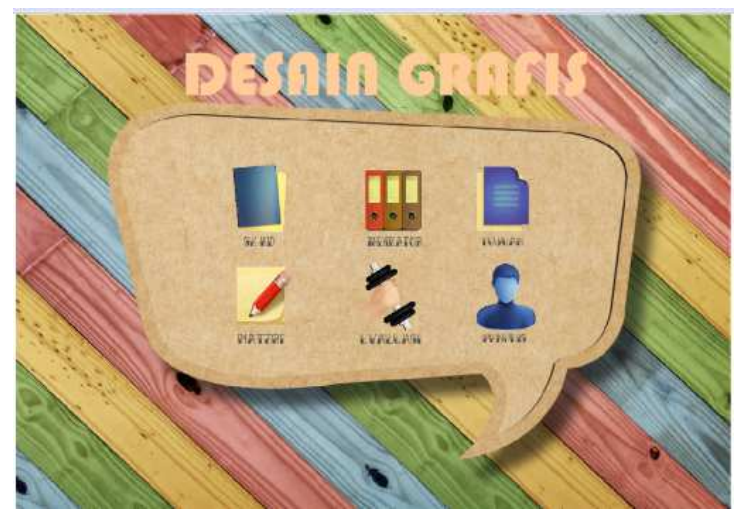

Gambar 3. Tampilan Halaman Menu Utama

Tampilan SK-KD berisi uraian tentang standar kompetensi dan kompetensi dasar. Tampilan SK-KD dapat dilihat pada gambar 4.

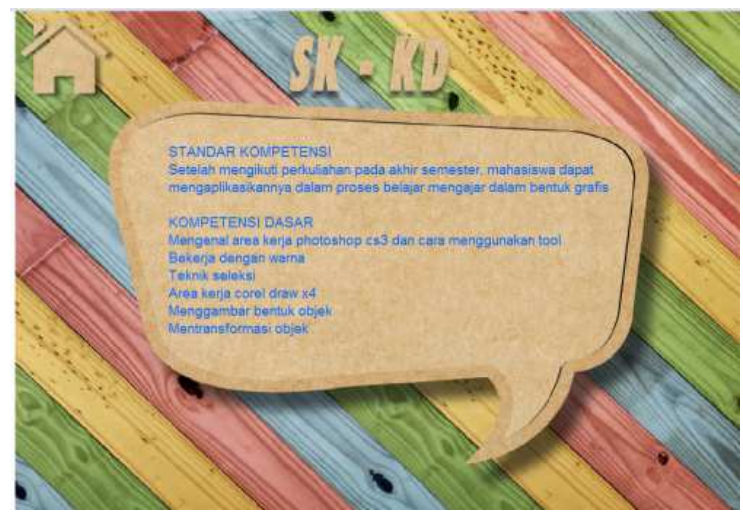

Gambar 4. Tampilan SK-KD 
Tampilan indikator berisi tentang pencapaian mahasiswa pada matakuliah desain grafis. Tampilan indikator dapat dilihat pada gambar 5 .

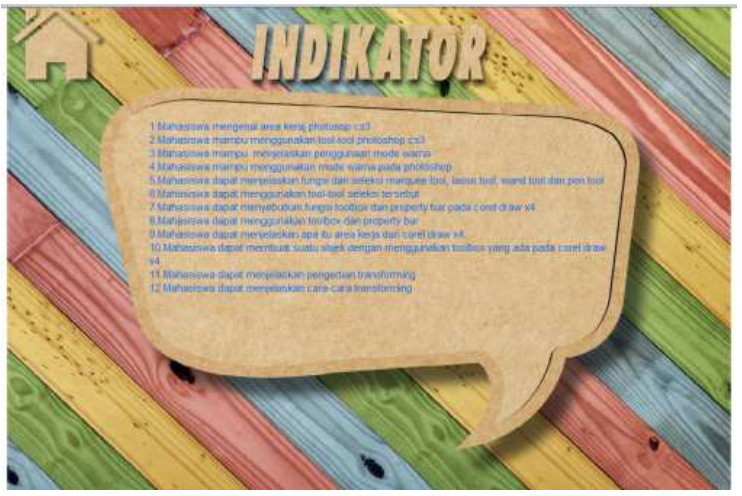

\section{Gambar 5. Tampilan Tujuan}

Tujuan berisi tentang tujuan setelah mempelajari modul elektronik. Tampilan tujuan dapat dilihat pada gambar 6 .

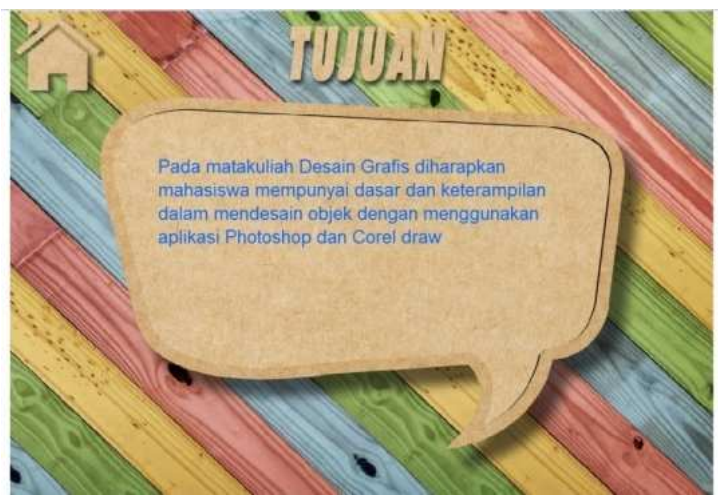

Gambar 6 Tampilan Tujuan

Tampilan materi berisi uraian materi yang dipelajari mahasiswa pada modul elektronik Desain Grafis. Contoh tampilan materi pada modul elektronik dapat dilihat pada gambar 7 .

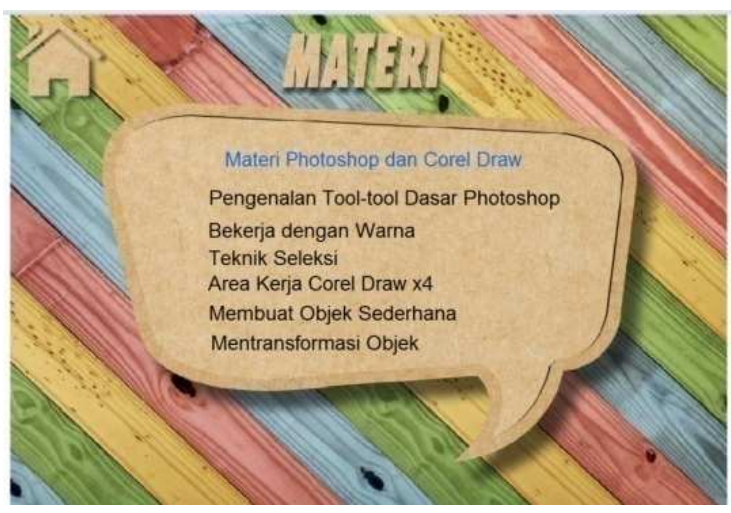

\section{Gambar 7. Tampilan Materi}

Tampilan uraian modul elektronik berisi uraian materi photoshop dan corel draw. Tampilan uraian materi dapat dilihat pada gambar 8 .

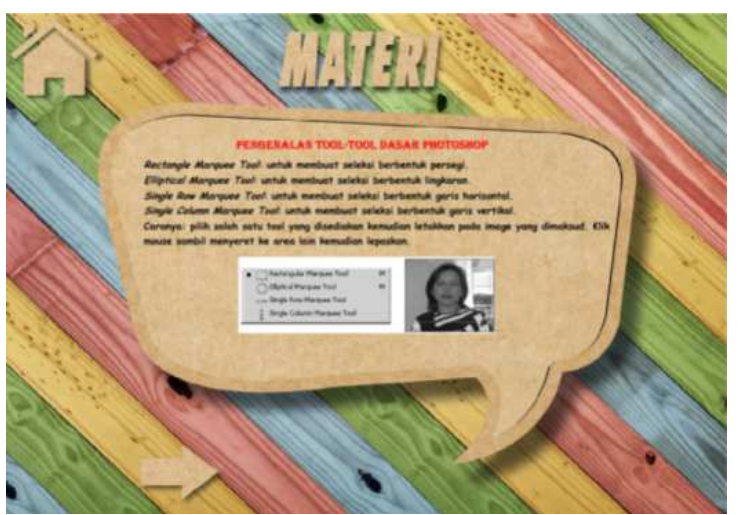

\section{Gambar 8. Tampilan Materi}

Tampilan evaluasi digunakan untuk menilai kemampuan mahasiswa ketika mereka sudah mempelajari semua materi dalam bentuk soal pilihan ganda. Berikut adalah contoh tampilan evaluasi.

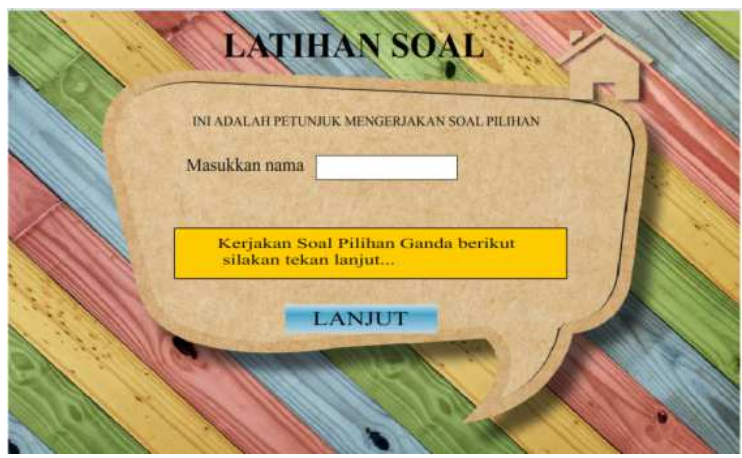

Gambar 9. Tampilan Evaluasi

Pada halaman evaluasi, mahasiswa memasukkan nama kemudian menekan tombol lanjut. Tampilan isi soal berupa pilihan ganda seperti pada gambar 10 .

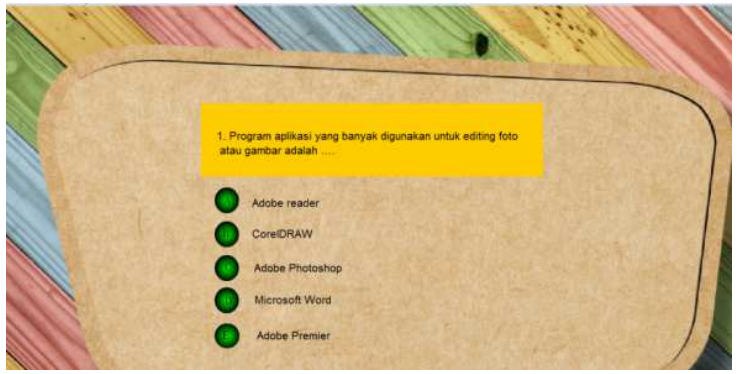

Gambar 10. Tampilan soal 
Setelah mahasiswa mengerjakan soal pilihan ganda yaitu 20 butir soal, maka akan keluar hasil evaluasi nya berupa nilai. Tampilan hasil skor dapat dilihat pada gambar 11.

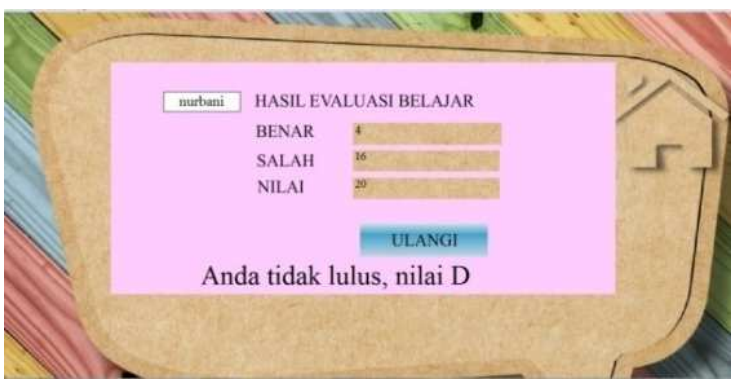

\section{Gambar 11. Tampilan Hasil Evaluasi}

Tahap selanjutnya modul dikemas dalam bentuk Compact Disc (CD) beserta instrumen penelitian,. validasi modul elektronik diberikan kepada dosen ahli materi dan dosen ahli media untuk mengetahui kelayakan produk pengembangan tersebut. Ahli materi terdiri dari dua orang dosen IKIP-PGRI Pontianak yang pernah mengajar materi Desain Grafis. Setelah di validasi dosen ahli materi, modul elektronik juga validasi oleh dosen ahli media yaitu dua orang dosen IKIPPGRI Pontianak yang ahli dalam bidang media pembelajaran.

Setelah di validasi dari dosen ahli materi dan dosen ahli media maka produk awal modul elektronik siap untuk diujicobakan kepada mahasiswa. Subjek ujicoba berikan kepada mahasiswa semester 2 dengan jumlah sampel 53 orang. Peneliti memandu secara langsung ujicoba dengan didampingi dosen pengampu matakuliah desain grafis. Pelaksanaan ujicoba berjalan dengan baik, para mahasiswa sangat berpartisipasi dan aktif melakukan apa yang diinstruksikan pada modul elektronik tersebut. Setelah di ujicoba ke mahasiswa kemudian diberikan angket kepada mahasiswa untuk mengetahui bagaiamana respon mahasiswa mengenai modul elektronik Desain Grafis. Jika ujicoba selesai dan tidak ada perbaikan modul elektronik maka produk modul ektronik bisa digunakan dalam proses pembelajaran.

Kelayakan produk pengembangan modul elektronik dinilai oleh dua orang dosen ahli materi yaitu dosen IKIP-PGRI Pontianak yang berkompeten dalam Desain Grafis. Adapaun hasil skor perhitungan angket kelayakan oleh dosen ahli materi dapat dilihat pada tabel 2.
Tabel 2. Rekapitulasi Kelayakan Ahli Materi

\begin{tabular}{llll}
\hline No & Validator & $\begin{array}{l}\text { Jumlah } \\
\text { Skor }\end{array}$ & Kriteria \\
\hline 1 & $\begin{array}{l}\text { Danar Santoso, } \\
\text { S.Kom., M.Pd. }\end{array}$ & 97 & Layak \\
& $\begin{array}{l}\text { Henny } \\
\text { Puspitasari, } \\
\text { S.Kom, M.Pd. }\end{array}$ & 92 & Layak \\
$\begin{array}{l}\text { Jumlah Rata-rata } \\
\text { Penilaian }\end{array}$ & 94,5 & Layak \\
\hline
\end{tabular}

Berdasarkan tabel 2 , skor penilaian dosen ahli materi adalah 102,5. Hasil skor tersebut dapat disimpulkan bahwa modul elektronik yang dikembangkan termasuk dalam kriteria layak.

Tabel 3. Kriteria Penilaian Angket Ahli Materi

\begin{tabular}{lll}
\hline No & Skor & Nilai \\
\hline 1 & $\bar{X}>117.6$ & Sangat Layak \\
2 & $95.2<\bar{X} \leq 117.6$ & Layak \\
3 & $72.8<\bar{X} \leq 95.2$ & Cukup Layak \\
4 & $50.4<\bar{X} \leq 72.8$ & Tidak Layak \\
5 & $\bar{X} \leq 50.4$ & Sangat Tidak \\
& & Layak \\
\hline
\end{tabular}

Perhitungan penilaian angket dosen ahli materi :

$$
\begin{aligned}
\bar{X} & =\frac{\sum X}{N} \\
& =\frac{205}{2} \\
& =102,5
\end{aligned}
$$

Hasil penilaian angket oleh dosen ahli materi diperoleh skor 102,5>72,8 termasuk dalam kategori layak modul elektronik digunakan

Modul elektronik dinilai kelayakannya oleh dua orang dosen ahli media yaitu dosen IKIP-PGRI Pontianak yang berkompeten pada bidang media pembelajaran. Perhitungan angket kelayakan media pembelajaran dapat dilihat pada tabel 4 . 
Tabel 4. Rekapitulasi Kelayakan Ahli Media

\begin{tabular}{llcl}
\hline No & Validator & $\begin{array}{c}\text { Jumlah } \\
\text { Skor }\end{array}$ & Kriteria \\
\hline 1 & $\begin{array}{l}\text { Isnania Lestari, } \\
\text { ST., M.Pd. }\end{array}$ & 110 & Layak \\
& $\begin{array}{l}\text { Vindo Feladi , } \\
\text { ST. M.Pd. }\end{array}$ & 95 & Layak \\
$\begin{array}{l}\text { Jumlah Rata-rata } \\
\text { Penilaian }\end{array}$ & 102,5 & Layak \\
\hline
\end{tabular}

Berdasarkan tabel 4 diperoleh rata- rata penilaian dosen ahli media adalah 94,5. Skor tersebut menunjukkan bahwa modul elektronik termasuk dalam kriteria layak.

Tabel 5. Kriteria Penilaian Angket Ahli Media

\begin{tabular}{lll}
\hline No & Skor & Kriteria \\
\hline 1 & $\bar{X}>96,61$ & Sangat Layak \\
2 & $78,2<\bar{X} \leq 96,61$ & Layak \\
3 & $59,8<\bar{X} \leq 78,2$ & Cukup Layak \\
4 & $41,39<\bar{X} \leq 59,8$ & Tidak Layak \\
5 & $\bar{X} \leq 41,39$ & Sangat Tidak \\
& & Layak \\
\hline
\end{tabular}

Perhitungan angket dosen ahli media:

$$
\begin{aligned}
\bar{X} & =\frac{\sum X}{N} \\
& =\frac{189}{2} \\
& =94.5
\end{aligned}
$$

Berdasarkan perhitungan angket dosen ahli media dengan nilai 94,5 > 59,8 dapat disimpulkan pada kategori layak.

Respon mahasiswa pada ujicoba dilakukan pada mahasiswa semester 2 Program Studi P.TIK dengan sampel 53 orang mahasiswa. Hasil perhitungan angket respon mahasiswa terhadap modul elektronik pada ujicoba dapat dilihat pada

\begin{tabular}{|c|c|c|c|}
\hline $\begin{array}{l}\text { Rata-rata } \\
\text { Responden }\end{array}$ & $\begin{array}{l}\text { Skor } \\
\text { Mahasiswa }\end{array}$ & $\begin{array}{l}\text { Skor } \\
\text { Angket }\end{array}$ & \\
\hline
\end{tabular}
tabel 9 .

Tabel 6. Rekapitulasi Angket Respon Mahasiswa

\begin{tabular}{lll}
\hline 108 & 4 & Baik \\
\hline
\end{tabular}

Pada tabel 6 dapat disimpulkan bahwa respon mahasiswa terhadap produk pengembangan modul elektronik ditunjukkan dengan skor rata-rata mahasiswa pada ujicoba adalah 108 dengan skor angket adalah 4. Hasil rata-rata skor angket respon siswa tersebut menunjukkan bahwa modul elektronik yang dikembangkan termasuk dalam kriteria baik.

Tabel 7. Katagori Respon Mahasiswa Terhadap Modul Elektronik

\begin{tabular}{ll}
\hline Skor Angket & Katagori \\
\hline $1,00-1,49$ & Tidak Baik \\
$1,50-2,49$ & Kurang Baik \\
$2,50-3,49$ & cukup \\
$3,50-4,49$ & Baik \\
$4,50-5,00$ & Sangat Baik \\
\hline
\end{tabular}

Penilaian angket respon siswa pada uji coba :

$$
\begin{aligned}
\bar{X} & =\frac{\sum X}{N} \\
& =\frac{108}{27} \\
& =4
\end{aligned}
$$

Berdasarkan hasil dari rata-rata skor angket dari 28 mahasiswa adalah $4>3,49$ jadi, hasil penilaian modul elektronik termasuk dalam kategori Baik.

\section{KESIMPULAN}

Adapun kesimpulan dari penelitian ini adalah sebagai berikut :

1. Pengembangan modul elektronik menggunakan model Borg and Gall yang memiliki beberapa tahap yaitu mencari potensi dan masalah, pengumpulan data, desain produk, validasi desain, revisi desain, validasi produku, jicoba pemakaian produk dan revisi produk

2. Penilaian modul elektronik oleh dosen ahli materi diperoleh skor 102,5 dengan kategori layak dan hasil penilaian modul elektronik oleh dosen ahli media diperoleh skor 94,5 dengan kategori layak. Sedangkan respon mahasiswa disimpulkana terhadap modul elektronik dalam 
ujicoba sampel 53 orang mahasiswa diperoleh rata-rata skor angket 4 dengan kriteria baik. Berdasarkan data tersebut dapat disimpulkan bahwa modul elektronik aplikasi desain grafis yang dikembangkan layak dan baik digunakan dalam proses pembelajaran.

\section{DAFTAR PUSTAKA}

[1] Mudhofir. Prinsip - prinsip Pengelolaan Pusat Sumber Belajar, Wahana Press. Bandung, 1990.

[2] Najikhah. Fatikhatun, "Keefektifan Multimedia Pembelajaran Interaktif Game Edukasi Dengan Adobe Flash Terhadap Hasil Belajar Pembelajaran IPA Mengenal Berbagai Benda Lagit di Kelas 1 SD N 2 Wergu Kulon Kudus". Jurnal Pendidikan, vol. 4, no. 2, Website: https://journal.unnes.ac.id/sju/index.ph $\mathrm{p} / \mathrm{jktp} /$ article/view/14307

[3] Sugiyono, Metode Penelitian Pendidikan (Pendekatan Kuantitatif, Kualitatif \& RND), Alfabeta. Bandung : 2014/.

[4] Sugiyono, Metode Penelitian Pendidikan pendekatan Kuantitatif, kualitatif, dan $R \& D$. Alfabeta, Bandung:, 2010.

[5] Sukarjo, Desain Pembelajaran: evaluasi pembelajaran. Hand-out perkuliahan: PPs Universitas Negeri Yogyakarta. 2006. 